\title{
Nanozyme sensor arrays based on heteroatom-doped graphene for detecting pesticides
}

\author{
Yunyao Zhu, ${ }^{1 \dagger}$ Jiangjiexing Wu, ${ }^{1 \dagger}$ Lijun Han, ${ }^{2}$ Xiaoyu Wang, ${ }^{1}$ Wei Li, ${ }^{3}$ Hongchao Guo, ${ }^{2 *}$ and Hui Wei ${ }^{1,45^{*}}$ \\ ${ }^{1}$ Department of Biomedical Engineering, College of Engineering and Applied Sciences, Nanjing National Laboratory of \\ Microstructures, Jiangsu Key Laboratory of Artificial Functional Materials, Chemistry and Biomedicine Innovation \\ Center (ChemBIC), Nanjing University, Nanjing, Jiangsu 210093, China. \\ ${ }^{2}$ Department of Chemistry, China Agricultural University, Beijing 100193, China. \\ ${ }^{3}$ Collaborative Innovation Center of Chemical Science and Chemical Engineering, School of Chemical Engineering \& \\ Technology, Tianjin University, Tianjin 300350, China. \\ ${ }^{4}$ State Key Laboratory of Analytical Chemistry for Life Science and State Key Laboratory of Coordination Chemistry, \\ School of Chemistry and Chemical Engineering, Nanjing University, Nanjing, Jiangsu 210023, China. \\ ${ }^{5}$ Key Laboratory of Analytical Chemistry for Biology and Medicine (Wuhan University), Ministry of Education, Wuhan \\ University, Wuhan, Hubei 430072, China. \\ ${ }^{\dagger}$ Equal contribution.
}




\section{Table of contents}

Figure S1. Chemical structures of 5 pesticides in this work: (a) lactofen, (b) fluoroxypyr-meptyl, (c) bensulfuron-methyl, (d) fomesafen, and (e) diafenthiuron.

Figure S2. Computational models: (a) NG, (b) GO, (c) NSG1, (d) NSG2, and (e) NSG3. Red circles indicated the investigated sites. C, gray; $\mathrm{H}$, white; $\mathrm{O}$, red; N, blue; S, yellow.

Figure S3. Computational models of 5 pesticides: (a) lactofen, (b) fluoroxypyr-meptyl, (c) bensulfuron-methyl, (d) fomesafen, and (e) diafenthiuron. $\mathrm{C}$, gray; H, white; O, red; N, blue; S, yellow; F, cyan; Cl, green.

Figure S4. XPS survey scan and elemental composition of (a) NG and (b) NSG.

Figure S5. Typical adsorption spectra of $100 \mathrm{mM} \mathrm{NaOAc-HOAc} \mathrm{buffer} \mathrm{(pH} \mathrm{4.0)} \mathrm{containing} 1 \mathrm{mM} \mathrm{H}_{2} \mathrm{O}_{2}$ and $0.5 \mathrm{mM}$ TMB in the absence (black) and presence of $10 \mu \mathrm{g} / \mathrm{mL} \mathrm{NG} \mathrm{(red),} 20 \mu \mathrm{g} / \mathrm{mL} \mathrm{GO}$ (green), or $20 \mu \mathrm{g} / \mathrm{mL} \mathrm{NSG} \mathrm{(blue)} \mathrm{after}$ incubation at $37^{\circ} \mathrm{C}$ for 30 minutes.

Figure S6. (a) Normalized peroxidase-mimicking activity of GO after incubation with $100 \mu \mathrm{M}$ pesticides. (b-f) Peroxidase-mimicking activity of GO after incubation with different concentrations of (b) lactofen, (c) fluoroxypyr-meptyl, (d) bensulfuron-methyl, (e) fomesafen, and (f) diafenthiuron. Pesticides 1-5: lactofen, fluoroxypyr-meptyl, bensulfuron-methyl, fomesafen, and diafenthiuron.

Figure S7. (a) Normalized peroxidase-mimicking activity of NSG after incubation with $100 \mu \mathrm{M}$ pesticides. (b-f) Peroxidase-mimicking activity of NSG after incubation with different concentrations of (b) lactofen, (c) fluoroxypyr-meptyl, (d) bensulfuron-methyl, (e) fomesafen, and (f) diafenthiuron. Pesticides 1-5: lactofen, fluoroxypyr-meptyl, bensulfuron-methyl, fomesafen, and diafenthiuron.

Figure S8. GO surface with adsorbed pesticides: (a) lactofen, (b) fluoroxypyr-meptyl, (c) bensulfuron-methyl, (d) fomesafen, and (e) diafenthiuron. $\mathrm{C}$, gray; H, white; O, red; N, blue; S, yellow; F, cyan; Cl, green.

Figure S9. NSG1 surface with adsorbed pesticides: (a) lactofen, (b) fluoroxypyr-meptyl, (c) bensulfuron-methyl, (d) fomesafen, and (e) diafenthiuron. $\mathrm{C}$, gray; H, white; O, red; N, blue; S, yellow; F, cyan; Cl, green.

Figure S10. NSG2 surface with adsorbed pesticides: (a) lactofen, (b) fluoroxypyr-meptyl, (c) bensulfuron-methyl, (d) fomesafen, and (e) diafenthiuron. $\mathrm{C}$, gray; H, white; O, red; N, blue; S, yellow; F, cyan; Cl, green.

Figure S11. NSG3 surface with adsorbed pesticides: (a) lactofen, (b) fluoroxypyr-meptyl, (c) bensulfuron-methyl, (d) fomesafen, and (e) diafenthiuron. C, gray; H, white; O, red; N, blue; S, yellow; F, cyan; Cl, green.

Figure S12. Colorimetric response patterns towards $5 \mu \mathrm{M}$ pesticides. Pesticides 1-5: lactofen, fluoroxypyr-meptyl, bensulfuron-methyl, fomesafen, and diafenthiuron. 
Figure S13. (a) Colorimetric response patterns toward $10 \mu \mathrm{M}$ pesticides. (b) Canonical score plot for the colorimetric response patterns obtained against $10 \mu \mathrm{M}$ pesticides. Pesticides 1-5: lactofen, fluoroxypyr-meptyl, bensulfuron-methyl, fomesafen, and diafenthiuron.

Figure S14. (a) Colorimetric response patterns toward $20 \mu \mathrm{M}$ pesticides. (b) Canonical score plot for the colorimetric response patterns obtained against $20 \mu \mathrm{M}$ pesticides. Pesticides 1-5: lactofen, fluoroxypyr-meptyl, bensulfuron-methyl, fomesafen, and diafenthiuron.

Figure S15. (a) Colorimetric response patterns toward $50 \mu \mathrm{M}$ pesticides. (b) Canonical score plot for the colorimetric response patterns obtained against $50 \mu \mathrm{M}$ pesticides. Pesticides 1-5: lactofen, fluoroxypyr-meptyl, bensulfuron-methyl, fomesafen, and diafenthiuron.

Figure S16. (a) Colorimetric response patterns toward $100 \mu \mathrm{M}$ pesticides. (b) Canonical score plot for the colorimetric response patterns obtained against $100 \mu \mathrm{M}$ pesticides. Pesticides 1-5: lactofen, fluoroxypyr-meptyl, bensulfuron-methyl, fomesafen, and diafenthiuron.

Figure S17. (a) Colorimetric response patterns toward $200 \mu \mathrm{M}$ pesticides. (b) Canonical score plot for the colorimetric response patterns obtained against $200 \mu \mathrm{M}$ pesticides. Pesticides 1-5: lactofen, fluoroxypyr-meptyl, bensulfuron-methyl, fomesafen, and diafenthiuron.

Figure S18. Colorimetric response patterns toward $500 \mu \mathrm{M}$ pesticides. Pesticides 1-5: lactofen, fluoroxypyr-meptyl, bensulfuron-methyl, fomesafen, and diafenthiuron.

Figure S19. Typical absorption spectra for the oxidation of TMB catalyzed by NG with different concentrations of (a) lactofen, (b) bensulfuron-methyl, (c) fomesafen, and (d) diafenthiuron.

Figure S20. Colorimetric response patterns toward $50 \mu \mathrm{M}$ pesticides in the presence of (a) $\mathrm{Fe}^{3+}$, (b) BSA, (c) the mixture of $\mathrm{Fe}^{3+}, \mathrm{Cu}^{2+}, \mathrm{Mn}^{2+}$, and $\mathrm{Co}^{2+}$, and (d) the mixture of BSA, Cyt $c$, GSH, and Cys. Pesticides 1-5: lactofen, fluoroxypyr-meptyl, bensulfuron-methyl, fomesafen, and diafenthiuron.

Table S1. The corresponding adsorption energies of pesticides onto different graphene models. Energy in $\mathrm{kcal} / \mathrm{mol}$. 
<smiles>CCOC(=O)C(C)OC(=O)c1cc(Oc2ccc(C(F)(F)F)cc2Cl)ccc1[N+](=O)[O-]</smiles><smiles>CCCCCCC(C)OC(=O)COc1nc(F)c(Cl)c(N)c1Cl</smiles><smiles>COC(=O)c1ccccc1CS(=O)(=O)NC(=O)Nc1nc(OC)cc(OC)n1</smiles><smiles>CS(=O)(=O)NN(C(=O)O)C(=O)c1cc(Oc2ccc(C(F)(F)F)cc2Cl)ccc1[N+](=O)[O-]</smiles>

e<smiles>CC(C)c1cc(Oc2ccccc2)cc(C(C)C)c1NC(=S)NC(C)(C)C</smiles>

Figure S1. Chemical structures of 5 pesticides in this work: (a) lactofen, (b) fluoroxypyr-meptyl, (c) bensulfuron-methyl, (d) fomesafen, and (e) diafenthiuron. 


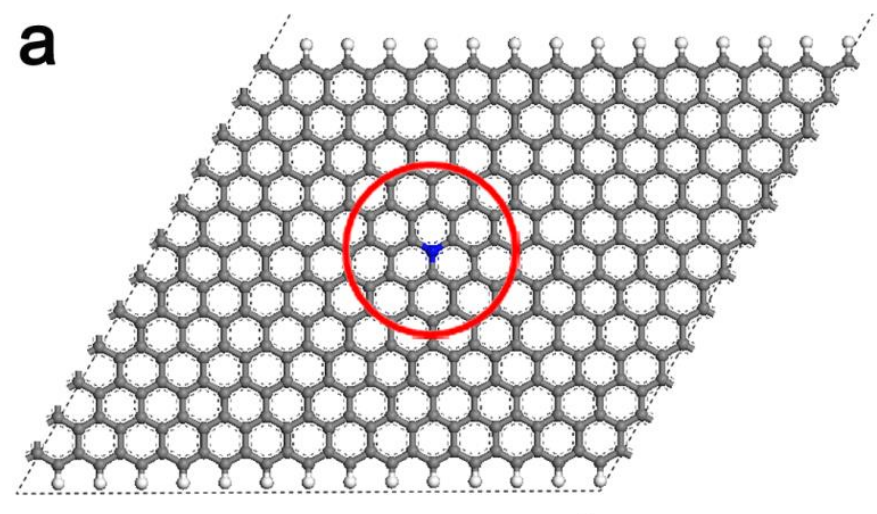

C

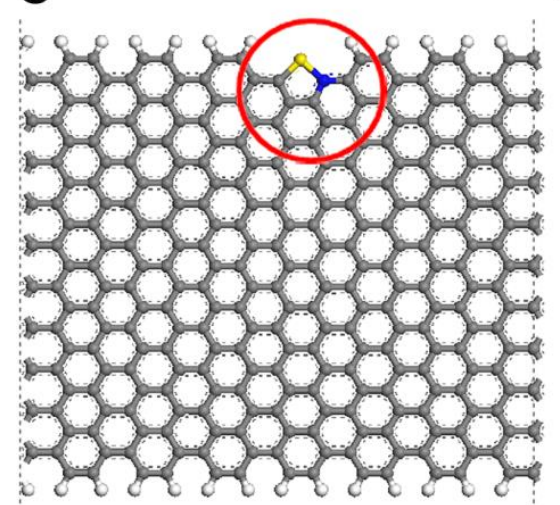

d

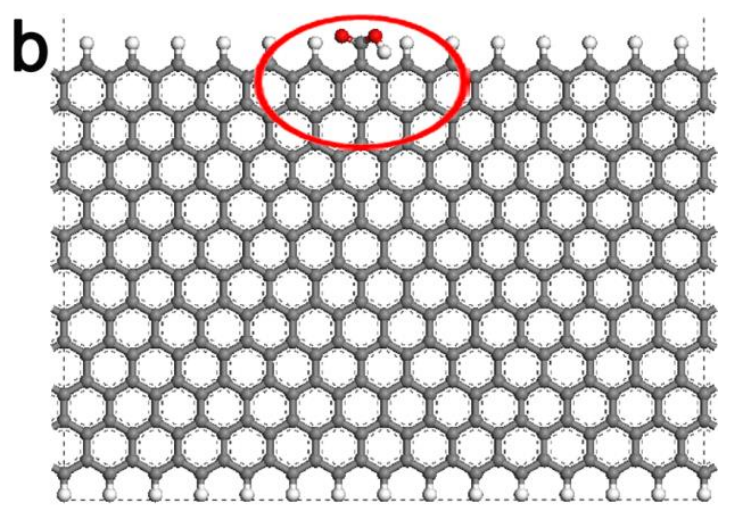

e
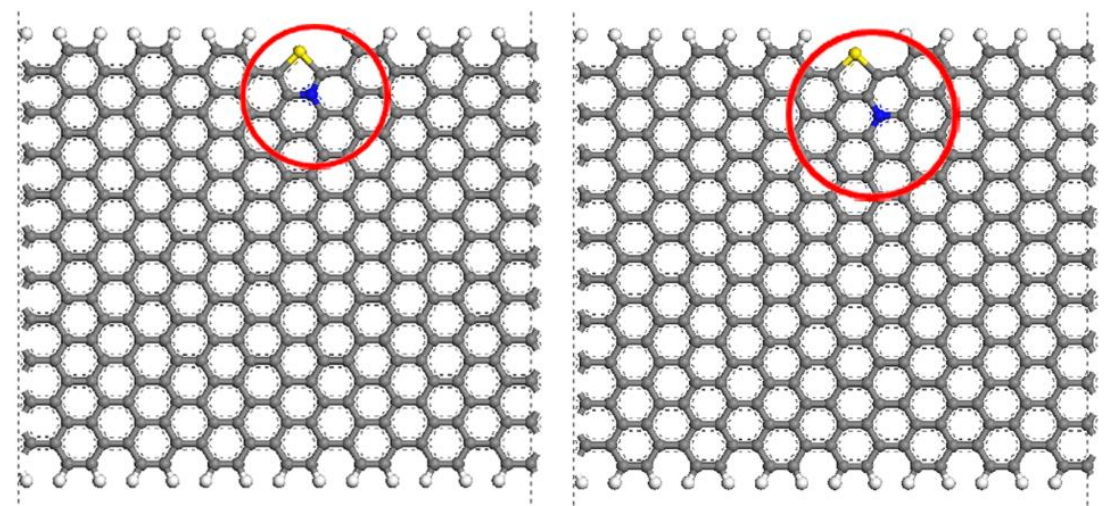

Figure S2. Computational models: (a) NG, (b) GO, (c) NSG1, (d) NSG2, and (e) NSG3. Red circles indicated the investigated sites. $\mathrm{C}$, gray; $\mathrm{H}$, white; $\mathrm{O}$, red; $\mathrm{N}$, blue; $\mathrm{S}$, yellow. 
a

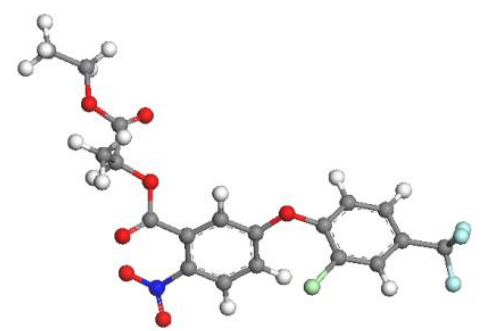

b

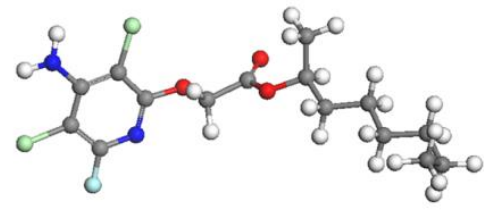

C

d

e
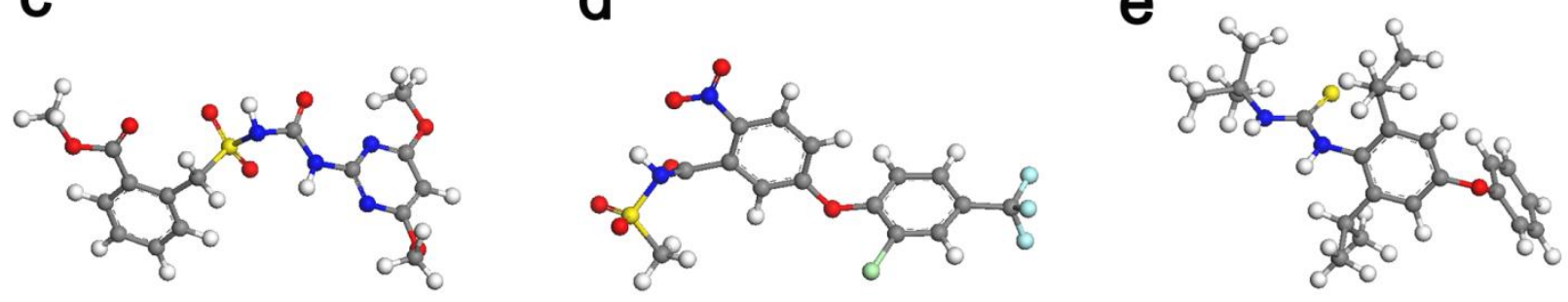

Figure S3. Computational models of 5 pesticides: (a) lactofen, (b) fluoroxypyr-meptyl, (c) bensulfuron-methyl, (d) fomesafen, and (e) diafenthiuron. $\mathrm{C}$, gray; $\mathrm{H}$, white; $\mathrm{O}$, red; $\mathrm{N}$, blue; $\mathrm{S}$, yellow; F, cyan; $\mathrm{Cl}$, green.

S-6 
a

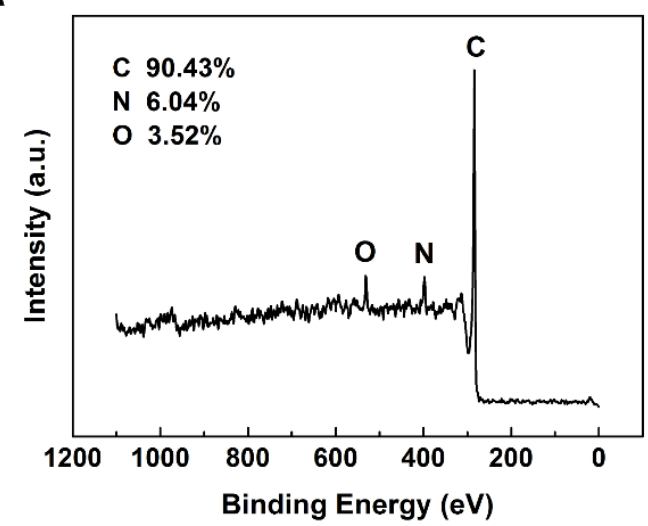

b

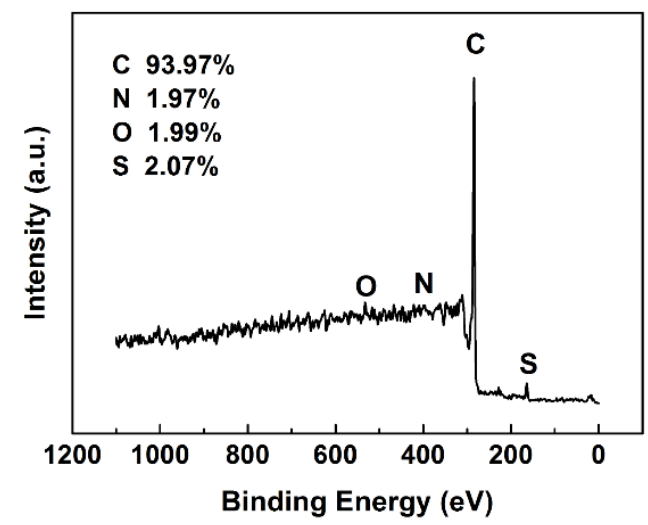

Figure S4. XPS survey scan and elemental composition of (a) NG and (b) NSG.

As shown in Figure S4, elemental compositions of NG and NSG were investigated. NG is composed of C, N, and O, accounting for $90.43 \%, 6.04 \%$, and $3.52 \%$, respectively. NSG is composed of $\mathrm{C}, \mathrm{N}, \mathrm{O}$, and $\mathrm{S}$, accounting for $93.97 \%$, $1.97 \%, 1.99 \%$, and $2.07 \%$, respectively. These results indicated the successful synthesis of NG and NSG. 


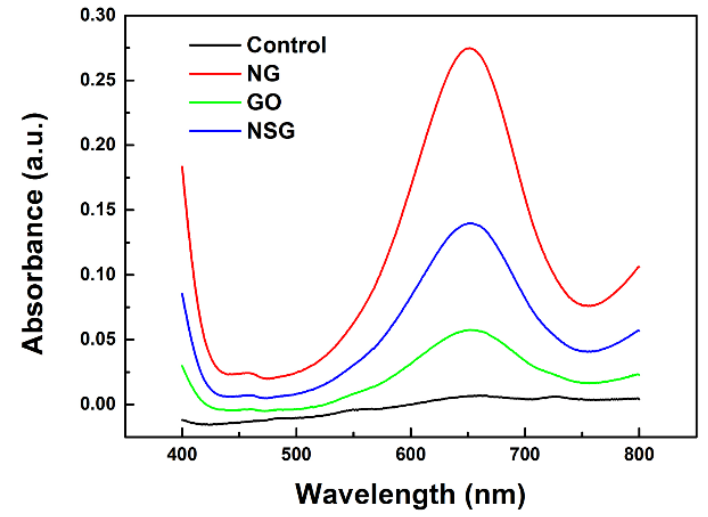

Figure S5. Typical adsorption spectra of $100 \mathrm{mM} \mathrm{NaOAc-HOAc}$ buffer ( $\mathrm{pH}$ 4.0) containing $1 \mathrm{mM} \mathrm{H}_{2} \mathrm{O}_{2}$ and $0.5 \mathrm{mM}$ TMB in the absence (black) and presence of $10 \mu \mathrm{g} / \mathrm{mL}$ NG (red), $20 \mu \mathrm{g} / \mathrm{mL}$ GO (green), or $20 \mu \mathrm{g} / \mathrm{mL}$ NSG (blue) after incubation at $37^{\circ} \mathrm{C}$ for 30 minutes. 
a
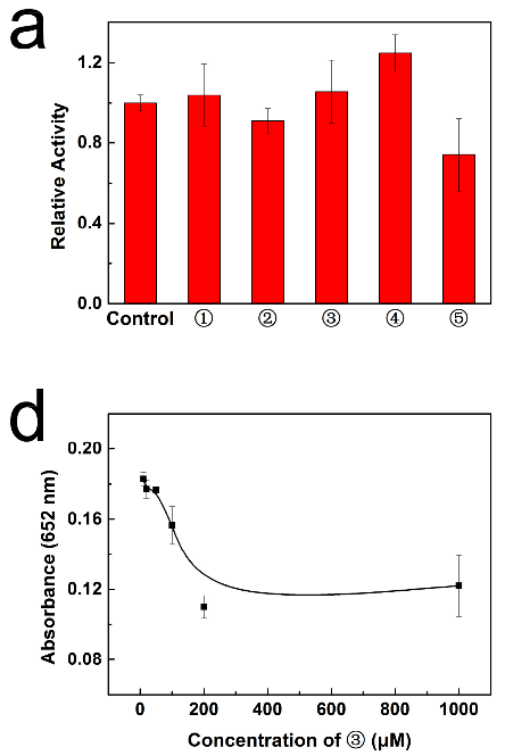

b

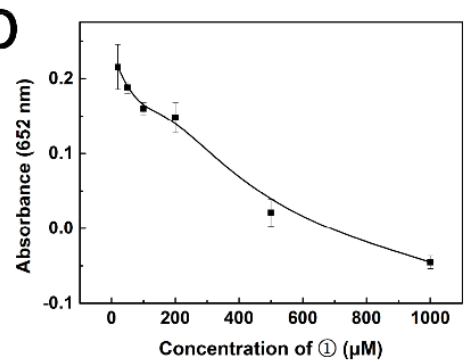

e

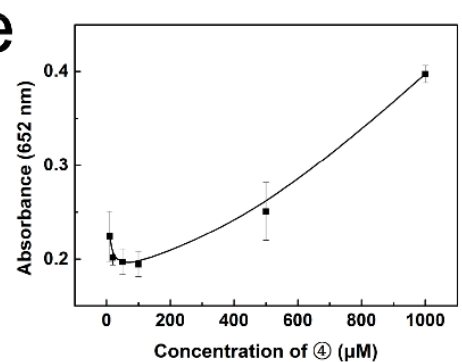

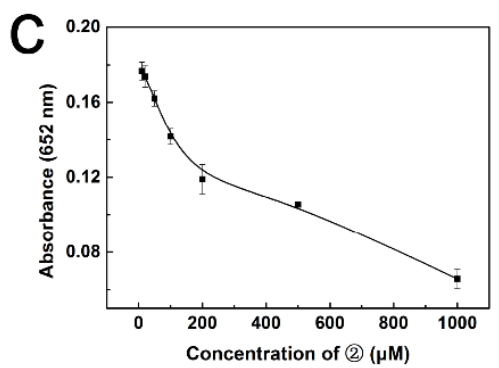

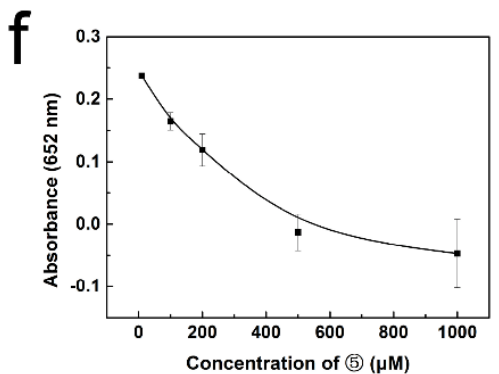

Figure S6. (a) Normalized peroxidase-mimicking activity of GO after incubation with $100 \mu \mathrm{M}$ pesticides. (b-f) Peroxidase-mimicking activity of GO after incubation with different concentrations of (b) lactofen, (c) fluoroxypyr-meptyl, (d) bensulfuron-methyl, (e) fomesafen, and (f) diafenthiuron. Pesticides 1-5: lactofen, fluoroxypyr-meptyl, bensulfuron-methyl, fomesafen, and diafenthiuron. 
a
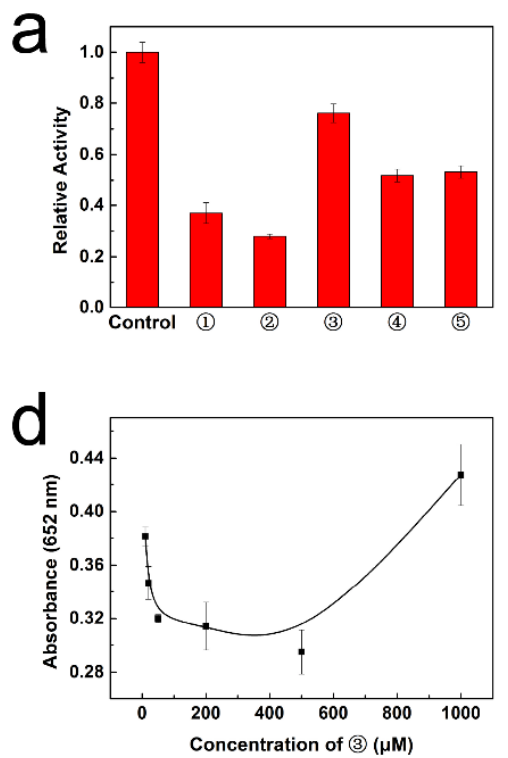

b
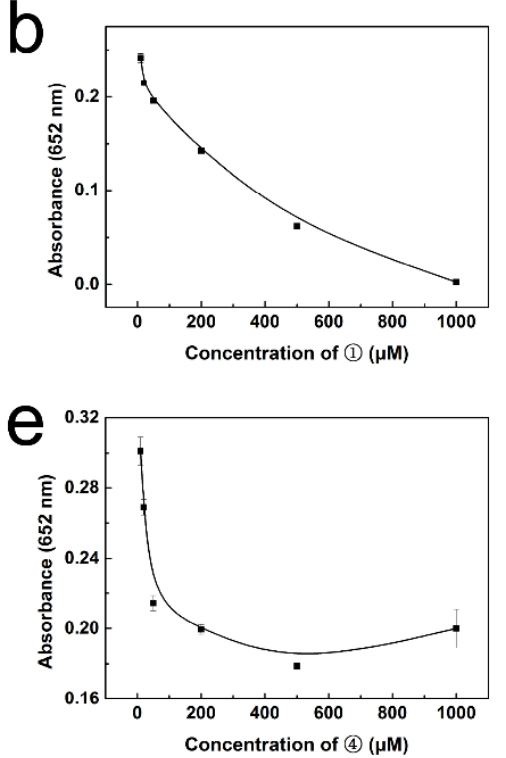
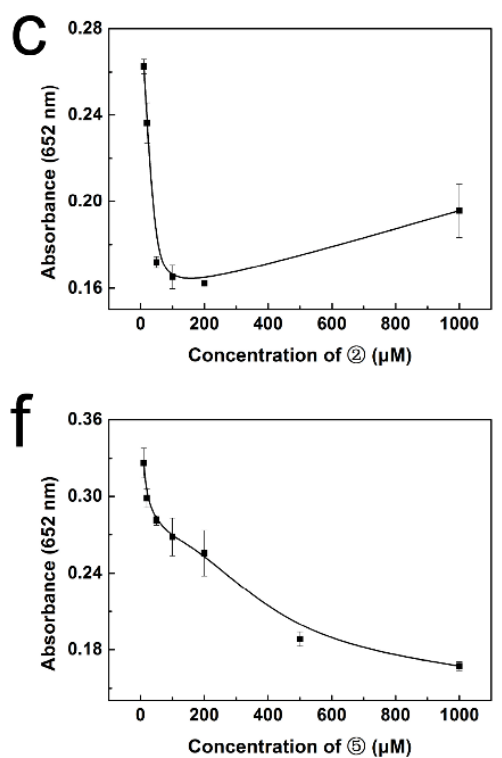

Figure S7. (a) Normalized peroxidase-mimicking activity of NSG after incubation with $100 \mu \mathrm{M}$ pesticides. (b-f) Peroxidase-mimicking activity of NSG after incubation with different concentrations of (b) lactofen, (c) fluoroxypyr-meptyl, (d) bensulfuron-methyl, (e) fomesafen, and (f) diafenthiuron. Pesticides 1-5: lactofen, fluoroxypyr-meptyl, bensulfuron-methyl, fomesafen, and diafenthiuron. 

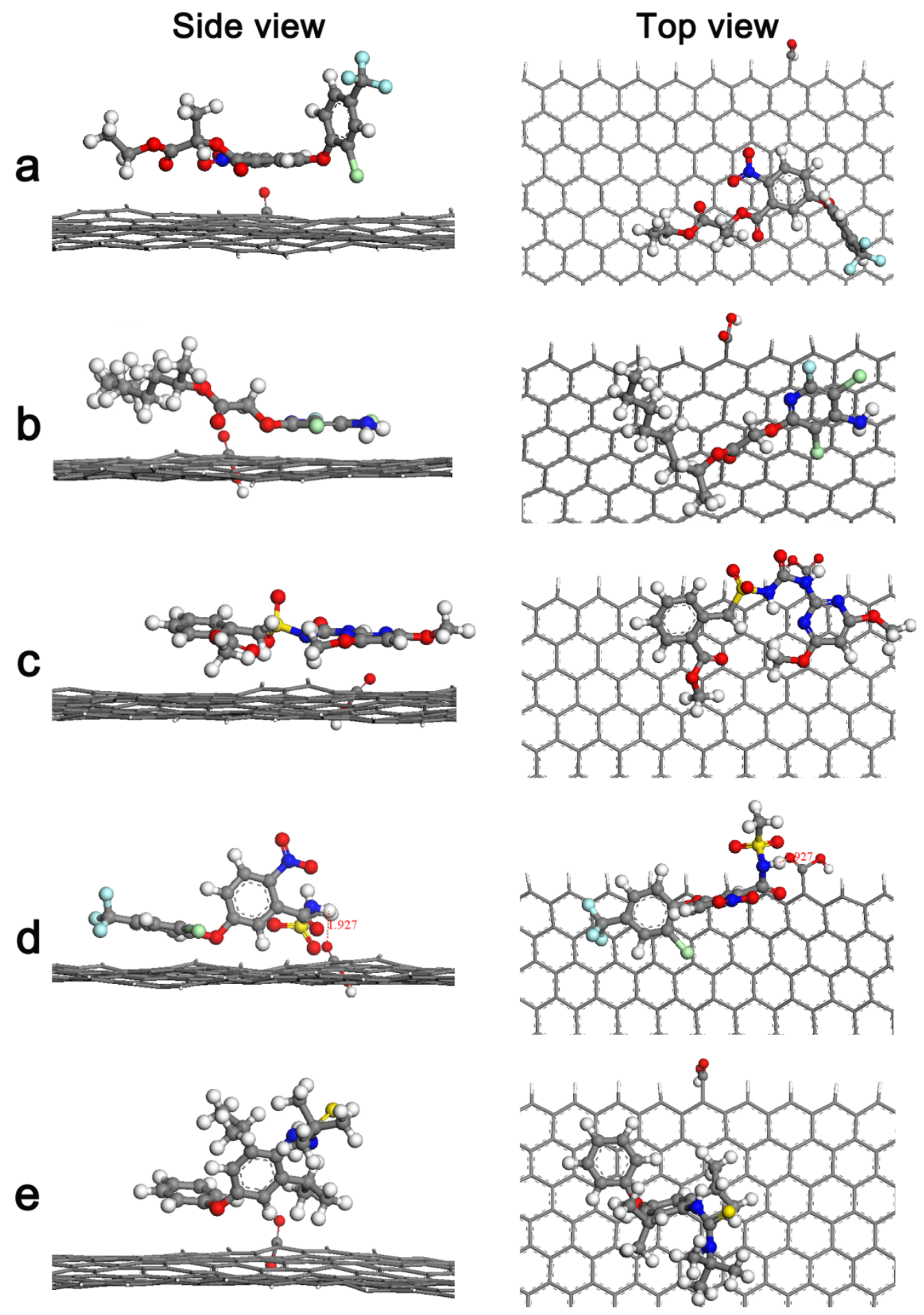

Figure S8. GO surface with adsorbed pesticides: (a) lactofen, (b) fluoroxypyr-meptyl, (c) bensulfuron-methyl, (d) fomesafen, and (e) diafenthiuron. $\mathrm{C}$, gray; $\mathrm{H}$, white; $\mathrm{O}$, red; N, blue; S, yellow; F, cyan; $\mathrm{Cl}$, green. 

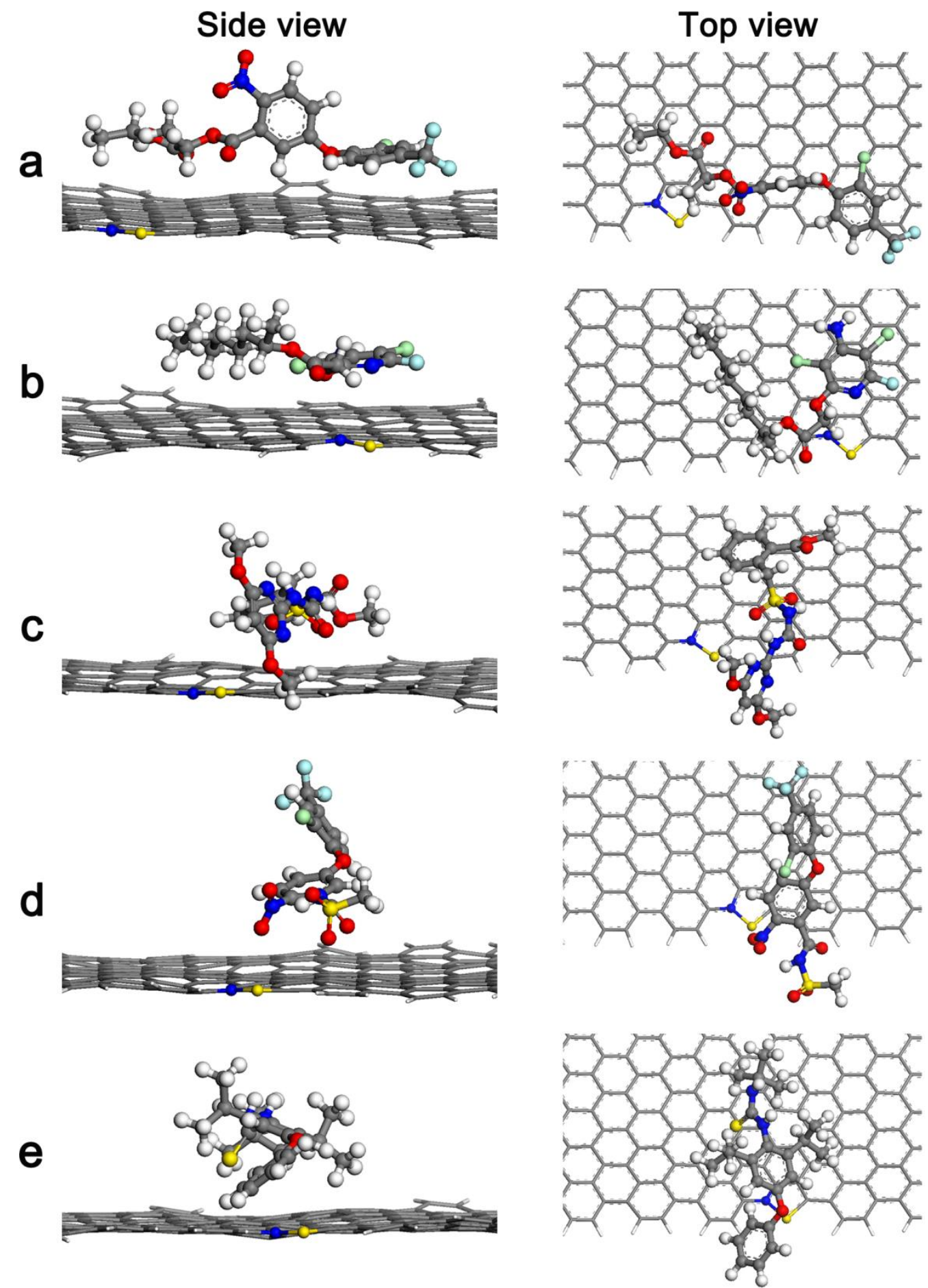

Figure S9. NSG1 surface with adsorbed pesticides: (a) lactofen, (b) fluoroxypyr-meptyl, (c) bensulfuron-methyl, (d) fomesafen, and (e) diafenthiuron. $\mathrm{C}$, gray; $\mathrm{H}$, white; $\mathrm{O}$, red; N, blue; S, yellow; F, cyan; $\mathrm{Cl}$, green. 
Side view

a

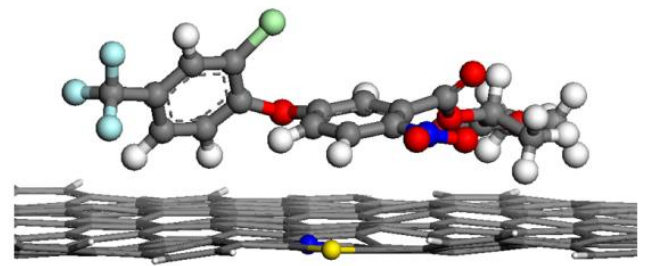

b
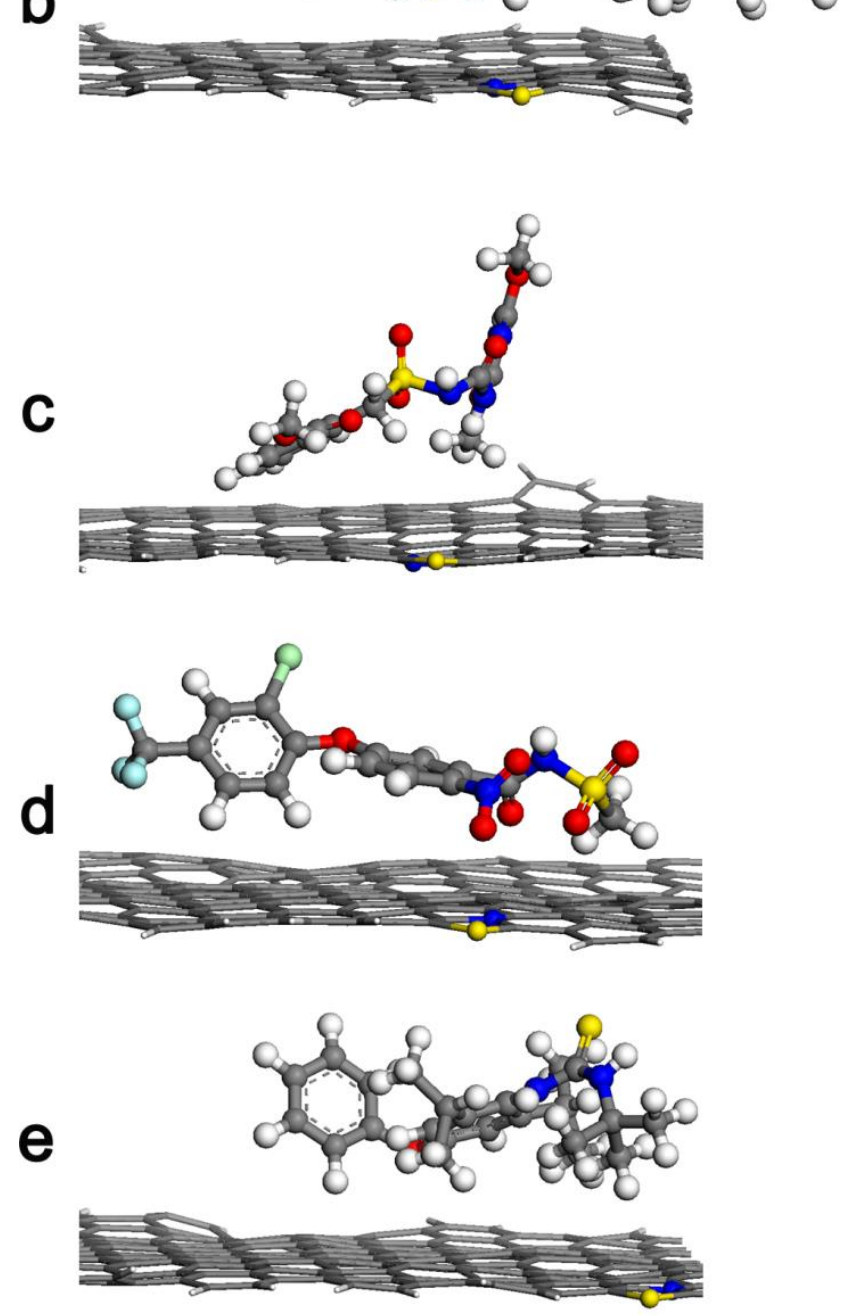
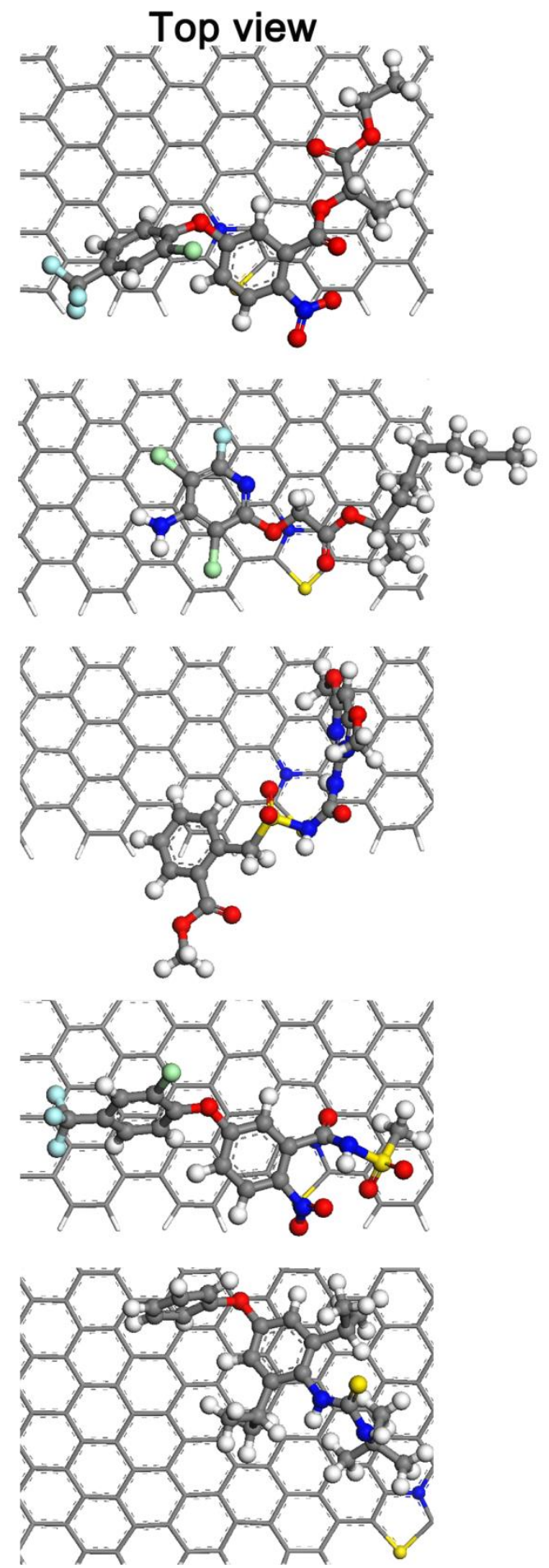

Figure S10. NSG2 surface with adsorbed pesticides: (a) lactofen, (b) fluoroxypyr-meptyl, (c) bensulfuron-methyl, (d) fomesafen, and (e) diafenthiuron. $\mathrm{C}$, gray; $\mathrm{H}$, white; $\mathrm{O}$, red; N, blue; S, yellow; $\mathrm{F}$, cyan; $\mathrm{Cl}$, green. 

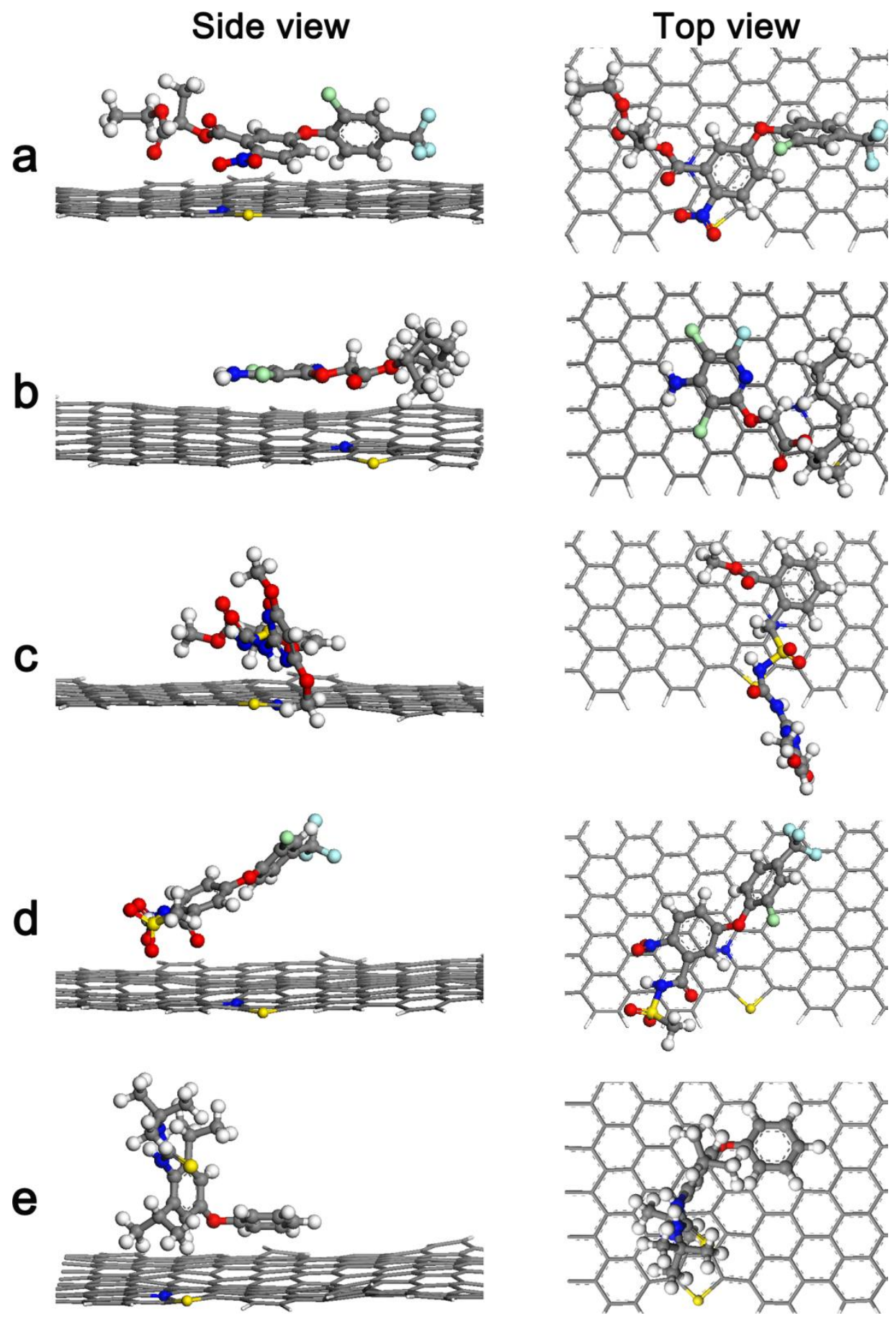

Figure S11. NSG3 surface with adsorbed pesticides: (a) lactofen, (b) fluoroxypyr-meptyl, (c) bensulfuron-methyl, (d) fomesafen, and (e) diafenthiuron. $\mathrm{C}$, gray; $\mathrm{H}$, white; $\mathrm{O}$, red; N, blue; $\mathrm{S}$, yellow; F, cyan; $\mathrm{Cl}$, green. 


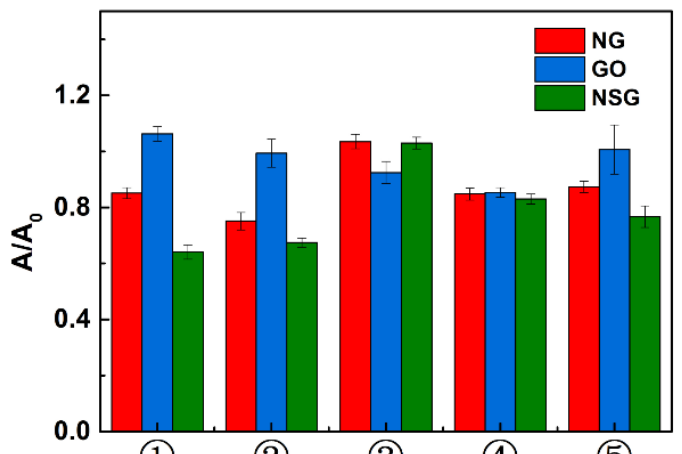

Figure S12. Colorimetric response patterns towards $5 \mu \mathrm{M}$ pesticides. Pesticides 1-5: lactofen, fluoroxypyr-meptyl, bensulfuron-methyl, fomesafen, and diafenthiuron. 
a

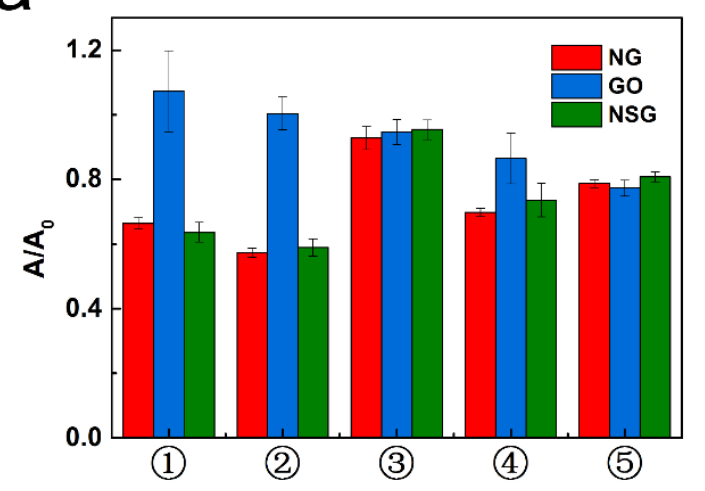

b

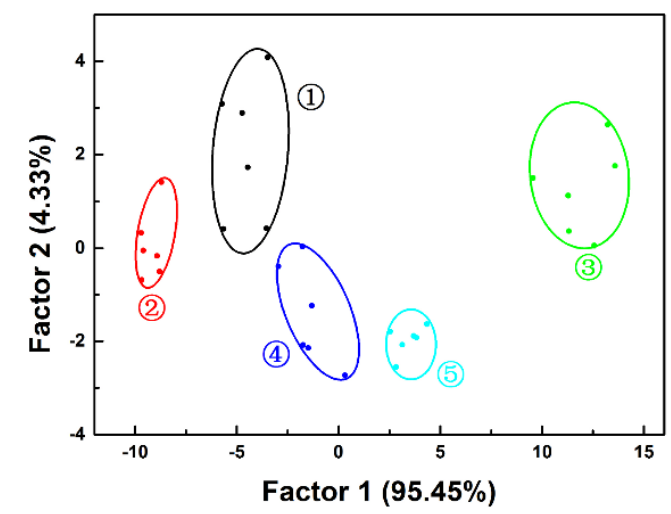

Figure S13. (a) Colorimetric response patterns toward $10 \mu \mathrm{M}$ pesticides. (b) Canonical score plot for the colorimetric response patterns obtained against $10 \mu \mathrm{M}$ pesticides. Pesticides 1-5: lactofen, fluoroxypyr-meptyl, bensulfuron-methyl, fomesafen, and diafenthiuron. 
a

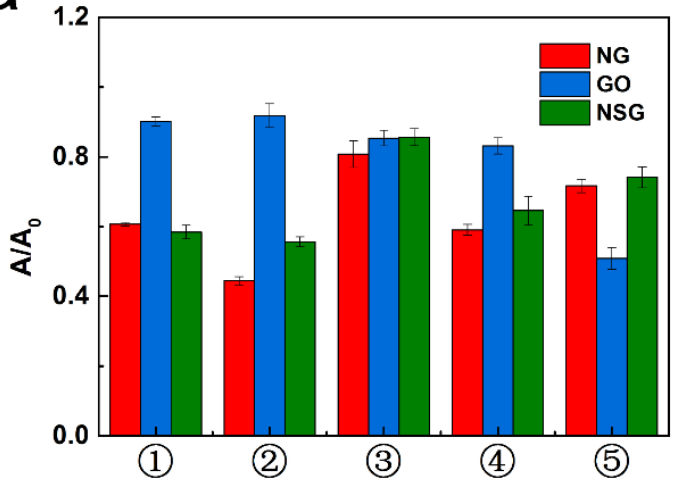

b

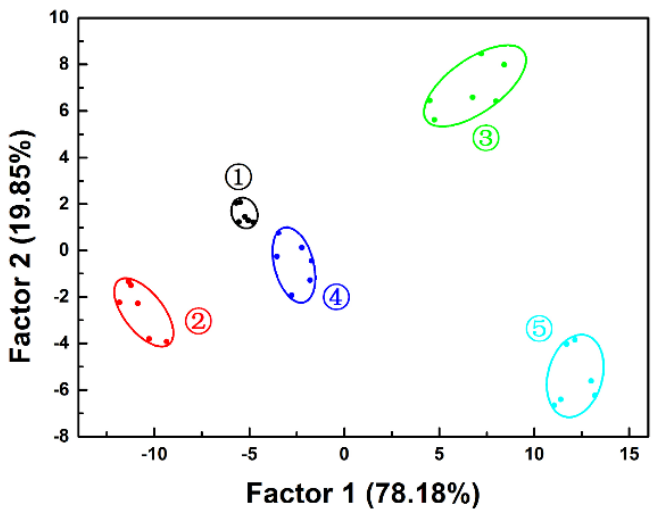

Figure S14. (a) Colorimetric response patterns toward $20 \mu \mathrm{M}$ pesticides. (b) Canonical score plot for the colorimetric response patterns obtained against $20 \mu \mathrm{M}$ pesticides. Pesticides 1-5: lactofen, fluoroxypyr-meptyl, bensulfuron-methyl, fomesafen, and diafenthiuron. 
a

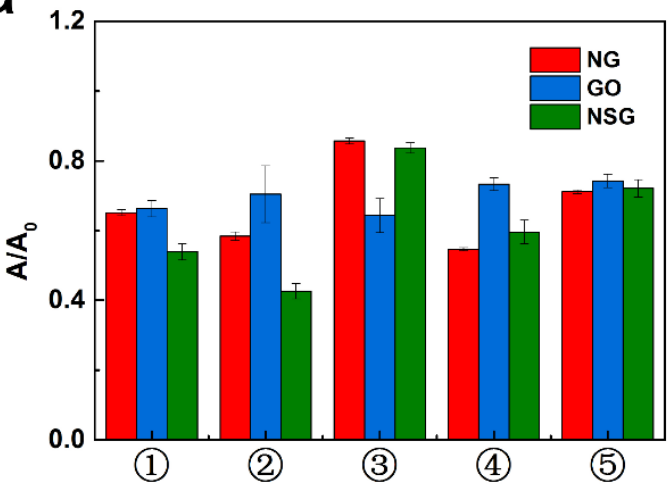

b

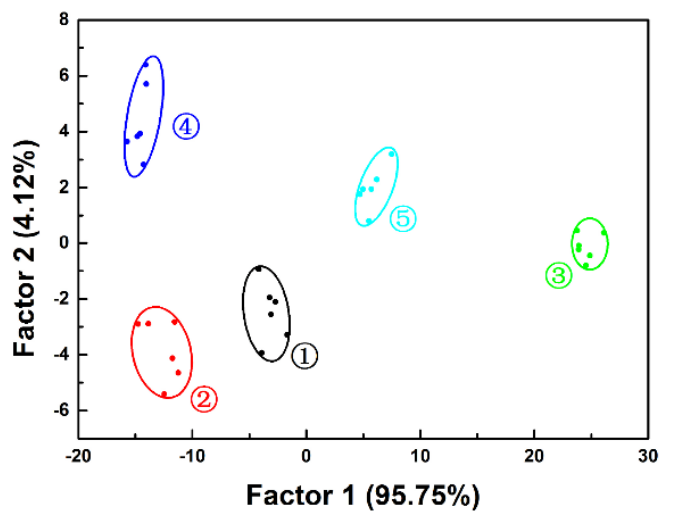

Figure S15. (a) Colorimetric response patterns toward $50 \mu \mathrm{M}$ pesticides. (b) Canonical score plot for the colorimetric response patterns obtained against $50 \mu \mathrm{M}$ pesticides. Pesticides 1-5: lactofen, fluoroxypyr-meptyl, bensulfuron-methyl, fomesafen, and diafenthiuron. 
a

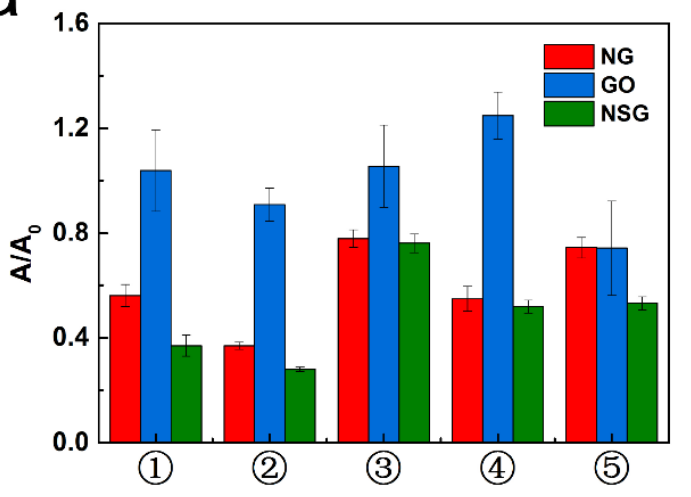

b

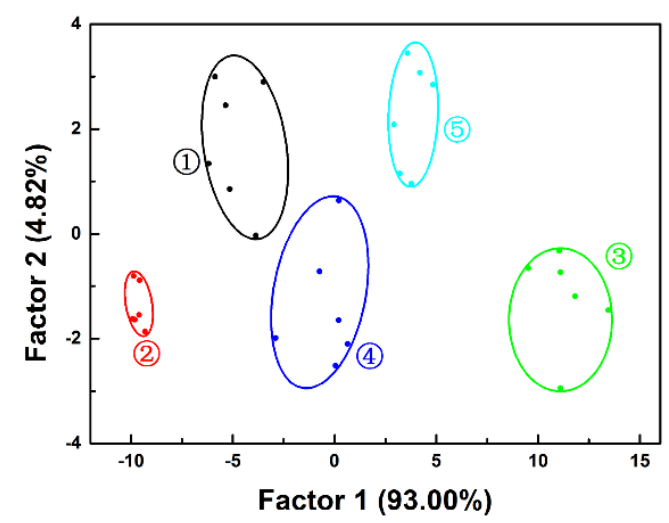

Figure S16. (a) Colorimetric response patterns toward $100 \mu \mathrm{M}$ pesticides. (b) Canonical score plot for the colorimetric response patterns obtained against $100 \mu \mathrm{M}$ pesticides. Pesticides 1-5: lactofen, fluoroxypyr-meptyl, bensulfuron-methyl, fomesafen, and diafenthiuron. 
a

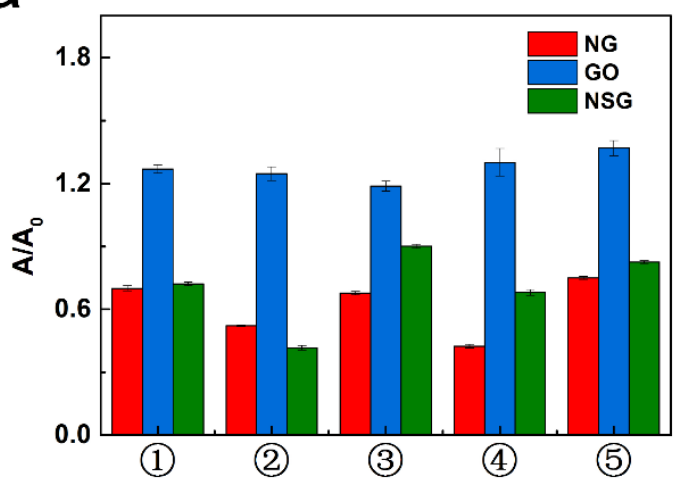

b

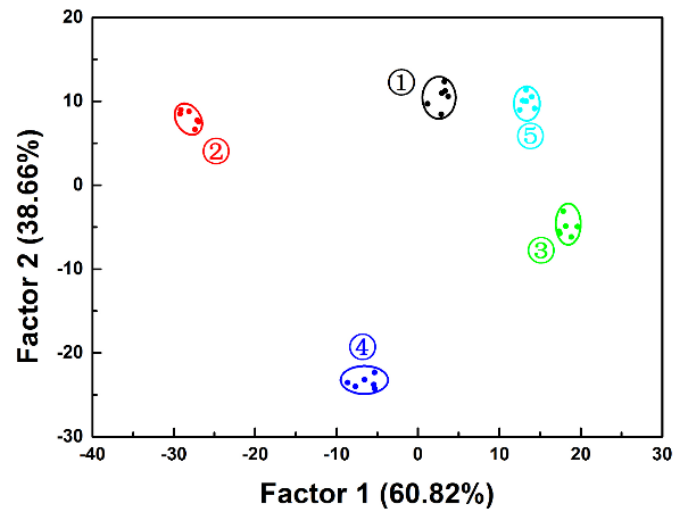

Figure S17. (a) Colorimetric response patterns toward $200 \mu \mathrm{M}$ pesticides. (b) Canonical score plot for the colorimetric response patterns obtained against $200 \mu \mathrm{M}$ pesticides. Pesticides 1-5: lactofen, fluoroxypyr-meptyl, bensulfuron-methyl, fomesafen, and diafenthiuron. 


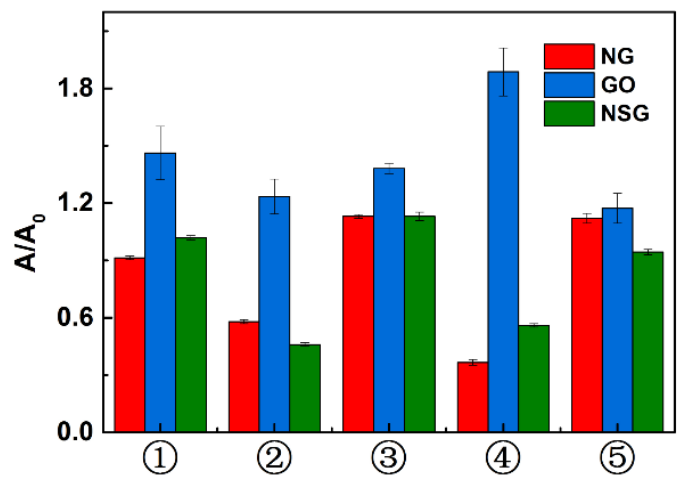

Figure S18. Colorimetric response patterns toward $500 \mu \mathrm{M}$ pesticides. Pesticides 1-5: lactofen, fluoroxypyr-meptyl, bensulfuron-methyl, fomesafen, and diafenthiuron. 
a

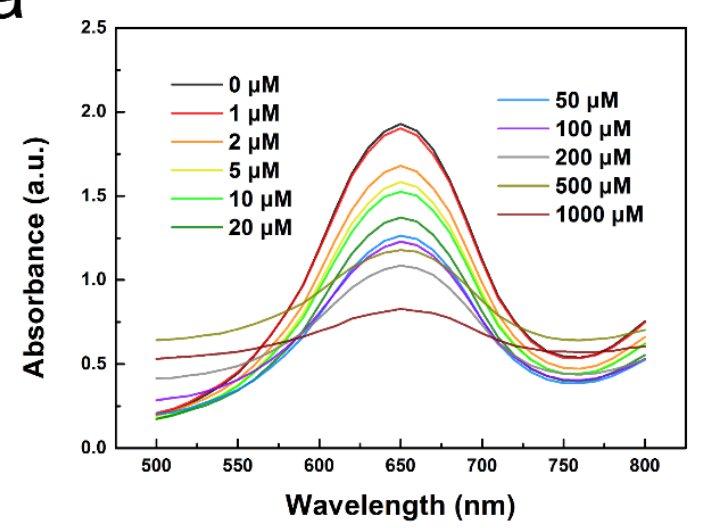

C

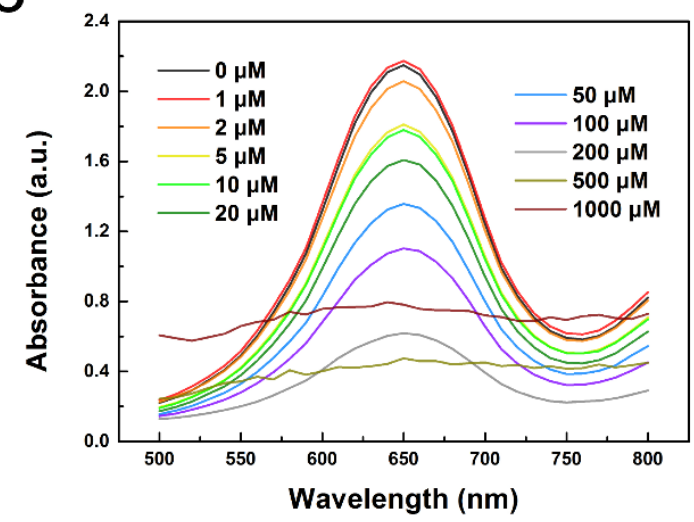

b

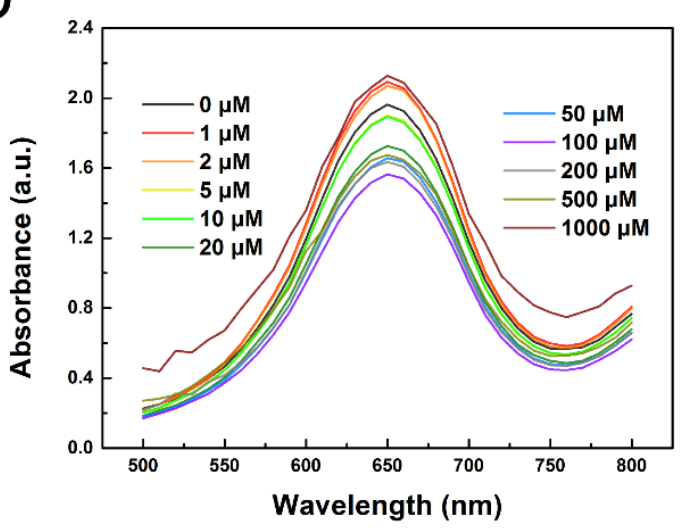

d

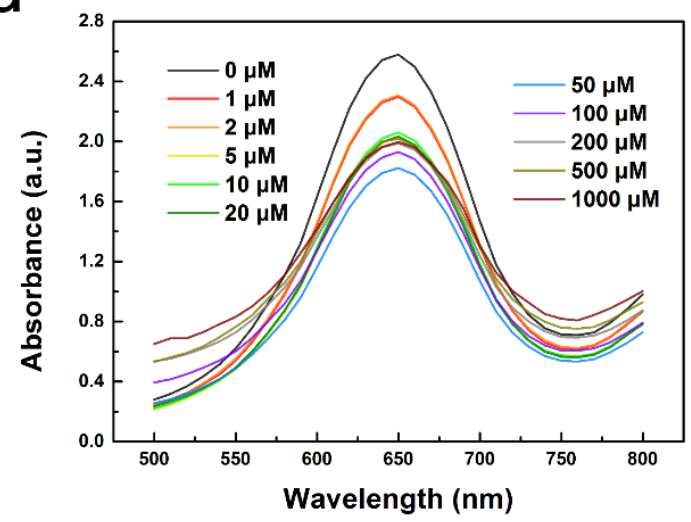

Figure S19. Typical absorption spectra for the oxidation of TMB catalyzed by NG with different concentrations of (a) lactofen, (b) bensulfuron-methyl, (c) fomesafen, and (d) diafenthiuron.

As shown in Figure S19, with the increase of concentration, the absorbance at $652 \mathrm{~nm}$ first decreased and then increased at high concentrations. It may be attributed to the low solubility of pesticides in water. With the increase of concentration, the solutions became turbid, leading to the increase of absorbance. 

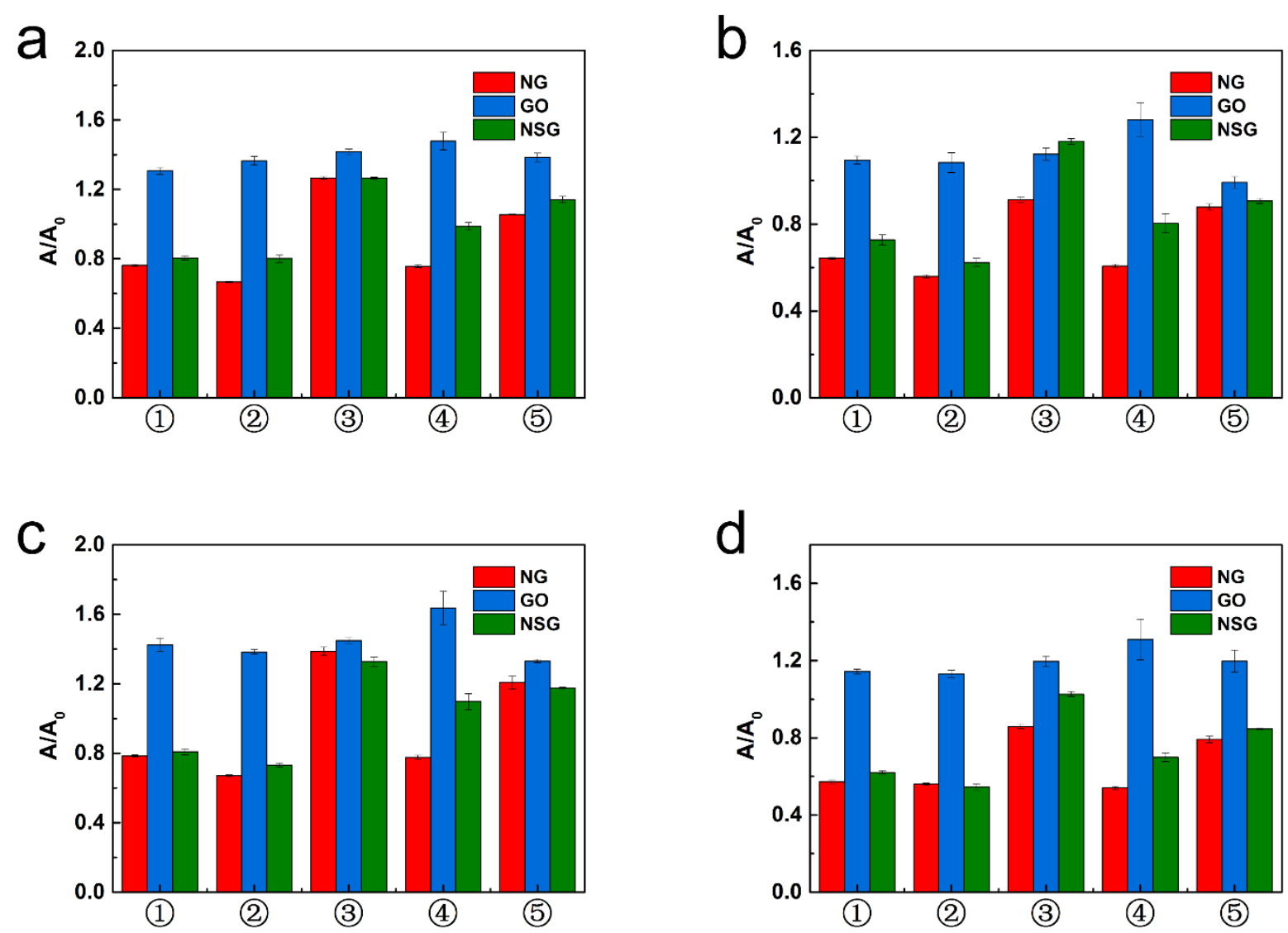

Figure S20. Colorimetric response patterns toward $50 \mu \mathrm{M}$ pesticides in the presence of (a) $\mathrm{Fe}^{3+}$, (b) BSA, (c) the mixture of $\mathrm{Fe}^{3+}, \mathrm{Cu}^{2+}, \mathrm{Mn}^{2+}$, and $\mathrm{Co}^{2+}$, and (d) the mixture of BSA, Cyt $c$, GSH, and Cys. Pesticides 1-5: lactofen, fluoroxypyr-meptyl, bensulfuron-methyl, fomesafen, and diafenthiuron. 
Table S1. The corresponding adsorption energies of pesticides onto different graphene models. Energy in $\mathrm{kcal} / \mathrm{mol}$.

\begin{tabular}{cccccc}
\hline & NG & GO & NSG1 & NSG2 & NSG3 \\
\hline Lactofen & 23.09 & 17.36 & 18.95 & 22.90 & 27.53 \\
Fluoroxypyr-meptyl & 24.42 & 26.58 & 21.45 & 17.83 & 28.34 \\
Bensulfuron-methyl & 20.97 & 30.99 & 16.15 & 12.24 & 18.24 \\
Fomesafen & 22.63 & 30.29 & 16.30 & 22.31 & 16.36 \\
Diafenthiuron & 21.83 & 25.06 & 21.30 & 17.64 & 21.58 \\
\hline
\end{tabular}

